\title{
Peripheral blood mononuclear cells isolated from patients with diabetic nephropathy show increased activation of the oxidative-stress sensitive transcription factor NF- $\mathrm{KB}$
}

\author{
M.A. Hofmann ${ }^{1}$, S. Schiekofer ${ }^{1}$, B. Isermann ${ }^{1}$, M. Kanitz ${ }^{1}$, M. Henkels ${ }^{1}$, M. Joswig ${ }^{1}$, A. Treusch ${ }^{1}$, M. Morcos ${ }^{1}$, \\ T. Weiss ${ }^{1}$, V. Borcea ${ }^{1}$, A. K. M. Abdel Khalek ${ }^{1}$, J. Amiral ${ }^{2}$, H. Tritschler ${ }^{3}$, E. Ritz ${ }^{1}$, P. Wahl ${ }^{1}$, R. Ziegler ${ }^{1}$, A. Bierhaus ${ }^{1}$, \\ P.P. Nawroth ${ }^{1}$ \\ ${ }^{1}$ Department of Medicine, University of Heidelberg, Heidelberg, Germany \\ ${ }^{2}$ Serbio Gennevilliers, France \\ ${ }^{3}$ ASTA Medica, Frankfurt am Main, Germany
}

\begin{abstract}
Summary Increased oxidative stress and subsequent activation of the transcription factor $\mathrm{NF}-\kappa \mathrm{B}$ has been linked to the development of late diabetic complications. To determine whether oxidative stress dependent NF- $\kappa \mathrm{B}$ activation is evident in patients with diabetic nephropathy we used an Electrophoretic Mobility Shift Assay based semiquantitative detection system which enabled us to determine NF- $\kappa \mathrm{B}$ activation in ex vivo isolated peripheral blood mononuclear cells. We examined 33 patients with diabetes mellitus (Type I and Type II). Patients with diabetic nephropathy showed higher NF- $\mathrm{BB}$ binding activity in Electrophoretic Mobility Shift Assays and stronger immunohistological staining for activated NF- $\kappa$ Bp65 than patients without renal complications. NF- $\mathrm{kB}$ binding activity correlated with the degree of albuminuria $(r=0.316)$ and with thrombomodulin plasma concentrations $(r=0.33)$, indicative for albuminuria
\end{abstract}

associated endothelial dysfunction. In a 3 day intervention study in which $600 \mathrm{mg}$ of the antioxidant thioctic acid ( $\alpha$-lipoic acid) per day were given to nine patients with diabetic nephropathy oxidative stress in plasma samples was decreased by $48 \%$ and $\mathrm{NF}-\kappa \mathrm{B}$ binding activity in ex vivo isolated peripheral blood mononuclear cells by $38 \%$.

In conclusion, activation of the transcription factor $\mathrm{NF}-\kappa \mathrm{B}$ in ex vivo isolated peripheral blood mononuclear cells of patients with diabetes mellitus correlates with the degree of diabetic nephropathy. NF$\kappa \mathrm{B}$ activation is at least in part dependent on oxidative stress since thioctic acid ( $\alpha$-lipoic acid) reduced NF- $\kappa \mathrm{B}$ binding activity. [Diabetologia (1999) 42: 222-232]

Keywords Oxidative stress, nephropathy, transcription factor NF- $\mathrm{KB}$, thrombomodulin, thioctic acid.
Increased oxidative stress generated by hyperglycaemia, hyperlipidaemia or the presence of advanced glycation endproducts (AGEs) or both is regarded as an important mediator of late diabetic complications [1]. A clear relation between the quality of gly-

Received: 21 January 1998 and in final revised from: 18 September 1998

Corresponding author: P.P. Nawroth, MD, University of Heidelberg, Department of Internal Medicine I, Bergheimer Strasse 58, D-69115 Heidelberg, Germany

Abbreviations: AGEs, Advanced glycation endproducts; BMI, body mass index; EMSA, electrophoretic mobility shift assay; 4-HNE, 4-hydroxynonenal; MDA, malonaldehyde; NF-кB, nuclear factor-kappa B; PBMC, peripheral blood mononuclear cells; PBS, phosphate buffered saline; rNF-кBp65, recombinant nuclear factor-kappa B subunit p65. caemic control and the presence of free radicals has been shown thereby relating the appearance of oxidative stress to the underlying metabolic disorder rather than to the complication itself [2]. The presence of oxygen free radicals and the simultaneous decline of antioxidative defence mechanisms observed in diabetic patients could therefore promote the development of late diabetic complications [1,3-5].

Oxidative stress has been proposed as a major cause of diabetic nephropathy [6-9]. Animal models implicate that oxidative stress accompanying the early onset of diabetes increases the kidney's susceptibility to develop diabetic nephropathy [10]. One possible mechanism for this is the activation of the oxidative stress sensitive transcription factor NF- $\kappa B$ [6, 11-13]. Translocation of activated NF- $\kappa B$ into the nucleus results in gene expression of $\mathrm{NF}-\kappa \mathrm{B}$ controlled 
Table 1. Characterisation of the 33 patients included in the cross-sectional study. Values represent the mean \pm SD obtained from 33 patients with diabetes mellitus, divided into two groups based on the urine albumin concentration as sign for diabetic nephropathy

\begin{tabular}{|c|c|c|c|}
\hline & $\begin{array}{l}\text { without diabetic nephropathy } \\
\text { (Urine albumin concentration } \\
<20 \mathrm{mg} / \mathrm{l}) n=12\end{array}$ & $\begin{array}{l}\text { with diabetic nephropathy } \\
\text { (Urine albumin concentration } \\
>300 \mathrm{mg} / \mathrm{l}) n=21\end{array}$ & $p$-Value \\
\hline $\operatorname{Sex}(m / f)$ & $6 / 6$ & $11 / 10$ & 0.899 \\
\hline Age (years) & $41.4 \pm 12.2$ & $53.3 \pm 13.0$ & 0.014 \\
\hline Duration of diabetes mellitus (years) & $16.3 \pm 8.5$ & $12.7 \pm 11.7$ & 0.358 \\
\hline $\mathrm{HbA}_{1 \mathrm{c}}(\%)$ & $7.2 \pm 1.09$ & $7.4 \pm 0.994$ & 0.67 \\
\hline Urine albumin concentration $(\mathrm{mg} / \mathrm{l})$ & $7.25 \pm 4.63$ & $106.5 \pm 62.2$ & 0.00004 \\
\hline $\operatorname{BMI}\left(\mathrm{kg} / \mathrm{m}^{2}\right)$ & $22.9 \pm 2.7$ & $26.1 \pm 2.62$ & 0.0019 \\
\hline Cholesterol (mg/dl) & $183.8 \pm 39.1$ & $223.6 \pm 57.1$ & 0.041 \\
\hline Systolic blood pressure $(\mathrm{mm} \mathrm{Hg})$ & $134.1 \pm 22.13$ & $126.5 \pm 1499$ & 0.243 \\
\hline Diastolic blood pressure $(\mathrm{mm} \mathrm{Hg})$ & $78.3 \pm 6.05$ & $75.2 \pm 8.08$ & 0.262 \\
\hline Antihypertensive drugs & $2(12)$ & $17(21)$ & 0.009 \\
\hline Prevalence of retinopathy & $4(12)$ & $7(21)$ & 0.792 \\
\hline Prevalence of neuropathy & $3(12)$ & $10(21)$ & 0.212 \\
\hline 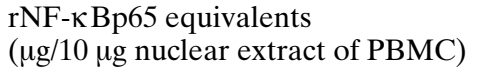 & $6.6 \pm 4.2$ & $13.7 \pm 9.4$ & 0.0004 \\
\hline Thrombomodulin (ng/ml) & $19.5 \pm 10.3$ & $34.0 \pm 17.8$ & 0.019 \\
\hline
\end{tabular}

target genes as leucocyte adhesion molecules, cytokines, renal epithelial-inducible nitric oxide synthase (eNOS), monocyte attractant protein-1 (MCP-1), endothelin-1 and tissue factor [12, 14-20]. Inducible $\mathrm{NF}-\kappa \mathrm{B}$ activation as response to hypoxia [21], cytokines [22, 23], angiotensin-II (Morcos and Nawroth, unpublished) or AGE-proteins [16, 24, 25] has been shown in glomerular mesangial cells $[11,20,22,23]$, tubular cells ([17], Morcos and Nawroth, unpublished), renal epithelial cells [19], the endothelium $[12,16,24,25]$ and monocytes/macrophages [26, 27]. In addition, in animal studies higher renal expression of the NF- $\mathrm{\kappa B}$ system in diabetic animals compared with healthy control animals has been observed [28].

Poor glycaemic control has been shown to induce activation of NF- $\mathrm{KB}$ in ex vivo isolated peripheral blood mononuclear cells (PBMC) of patients with Type I (insulin-dependent) diabetes mellitus [29]. To ascertain whether not only hyperglycaemia but also albuminuria can trigger a general increase in NF- $\kappa B$ activation in PBMC of patients with diabetes mellitus, we investigated $33 \mathrm{HbA}_{1 \mathrm{c}}$-matched patients with good glycaemic control by using a semiquantitative Electrophoretic Mobility Shift Assay (EMSA) based detection system [29]. In patients with diabetic nephropathy selected at random we did a 3 day intervention study to find out whether the observed activation of NF- $\kappa \mathrm{B}$ could be lowered by daily treatment with the antioxidant thioctic acid ( $\alpha$-lipoic acid), which has been shown to be a potent inhibitor of oxidative stress of NF- $\mathrm{KB}$ activation in vitro and in vivo [16, 29-33].

\section{Subjects and methods}

Patients. From our outpatient clinic, 33 patients matched for $\mathrm{HbA}_{1 \mathrm{c}}(7.4 \% \pm 0.9)$ with diabetes mellitus (17 male, $16 \mathrm{fe}-$ male; age $49.9 \pm 13.8$ years; duration of diabetes $14.0 \pm$ 10.7 years) were selected for our cross-sectional study. All patients underwent a full medical history including age, duration of diabetes, body mass index, eating habits, smoking habits, blood pressure, total cholesterol, urinary albumin concentration and a full examination to screen for diabetic complications (Table 1). Diagnosis of diabetic nephropathy was based on urinary albumin concentrations in the morning spot urine. Albuminuria was defined by urinary albumin concentrations higher than $21 \mathrm{mg} / \mathrm{l}$. The clinical diagnosis of diabetic retinopathy was based on the examination of the ocular fundus after dilatation of the pupils by experienced ophthamologists. Diagnosis of diabetic neuropathy was based on clinical assessment and measurement of the vibration perception threshold. Diabetic macroangiopathic complications were diagnosed according to clinical finding, doppler sonography and angiopathy. Of the patients with nephropathy $81 \%$ were on antihypertensive drugs; the patients that did not receive antihypertensive drugs entered the study when nephropathy was diagnosed. Patients treated with ACE-inhibitors and angiotension II-antagonists were excluded because angiotensin II modulates NF- $\mathrm{BB}$ activation (Morcos and Nawroth, unpublished). Patients taking vitamins or glucocorticoids were excluded from the study.

We selected at random nine patients matched for $\mathrm{HbA}_{1 \mathrm{c}}$ ( 5 male, 4 female; age $57.4 \pm 7.2$ years; duration of diabetes $12.3 \pm 9.06$; Table 2) with diabetic nephropathy and gave them $600 \mathrm{mg}$ of the antioxidant thioctic acid ( $\alpha$-lipoic acid) per day orally for 3 days. All patients included in this intervention study underwent a full medical history as described above and were taking antihypertensive drugs (Table 2) except ACE-inhibitors, AT-II antagonists, vitamins, glucocorticoids or antioxidants (aspirin was permissible). The study was approved by the ethics committee of the Department of Medicine, University of Heidelberg and informed consent had been obtained from all patients. 
Table 2. Characterisation of the 9 patients included in a 3 day intervention study with thioctic acid ( $\alpha$-lipoic acid). Nine at random selected patients with diabetic nephropathy were treated with $600 \mathrm{mg}$ thioctic acid ( $\alpha$-lipoic acid) per day orally for 3 days. NF- $\mathrm{KB}$ binding activity and enaldehyde concentrations (as measured for oxidative stress) were determined before and after intervention. Values represent the mean \pm SD

$\begin{array}{lll}\begin{array}{l}\text { before treatment } \\ \text { with thioctic acid }\end{array} & \begin{array}{l}\text { after } 3 \text { days treatment } \\ \text { with thioctic acid }\end{array} & p \text {-value }\end{array}$

$\operatorname{Sex}(\mathrm{m} / \mathrm{f})$

Age (years)

Duration of diabetes mellitus (years)

$\mathrm{HbA}_{1 \mathrm{c}}(\%)$

Urine albumin concentration $(\mathrm{mg} / \mathrm{l})$

BMI $\left(\mathrm{kg} / \mathrm{m}^{2}\right)$

Cholesterol $(\mathrm{mg} / \mathrm{dl})$

Systolic blood pressure $(\mathrm{mm} \mathrm{Hg})$

Diastolic blood pressure $(\mathrm{mm} \mathrm{Hg})$

Antihypertensive drugs

Prevalence of retinopathy

Prevalence of neuropathy

rNF- $\kappa$ Bp65 equivalents $(\mu \mathrm{g} / 10 \mu \mathrm{g}$ nuclear extract of PBMC)

Enaldehyde concentration $(\mu \mathrm{M})$ as measured for oxidative stress

$5 / 4$

$57.4 \pm 7.2$

$12.3 \pm 9.09$

$8.08 \pm 0.66$

$107.4 \pm 69.1$

$26.2 \pm 2.77$

$215.33 \pm 36.55$

$136.1 \pm 13.64$

$79.4 \pm 10.4$

$9(9)$

$5(9)$

$5(9)$

$16.01 \pm 7.31$

$5.01 \pm 1.5$

$9.00 \pm 5.14$

$2.71 \pm 0.96$

0.031

0.005
Clinical laboratory tests. Urine albumin concentration was determined in three overnight urine collections and analyzed by the nephelometric method (BNA, Behring-Werke, Marburg, Germany). $\mathrm{HbA}_{1 \mathrm{c}}$ concentrations were measured by HPLC (Diamat, Biorad, Munich, Germany; normal range 4.5$6.1 \%$ ). Thrombomodulin was determined using a two-site enzyme-linked immunoabsorbent assay (Asserachrom-Thrombomodulin-ELISA, Diagnostica Stago, Asniéres, France) according to the manufacturer's instructions as described previously [34].

Colorimetric assay for lipid peroxidation. As markers for lipid peroxidation malonaldehyde (MDA) and 4-hydroxy-3(E)nonenal (4-HNE) were determined as described previously [29] using the LPO-586 Kit (WAK-Chemie, Bad Soden, Germany) according to the manufacturer's instruction. Blood was collected into syringes containing $3.8 \%$ sodium citrate $(9: 1$; $\mathrm{vol} / \mathrm{vol}$ ) and centrifuged before $200 \mu \mathrm{l}$ of plasma supernatant were incubated for $40 \mathrm{~min}$ at $45^{\circ} \mathrm{C}$ with the chromogenic substrate R1, which reacts with MDA and 4-HNE to form stable chromophores with an absorbance maximum at about 586 $\mathrm{nm}$. At the end of incubation samples were centrifuged at $10000 \times g$ for $10 \mathrm{~min}$, the clear supernatant was used for measurement of absorbance at $586 \mathrm{~nm}$ and compared with standard curves for MDA and 4-HNE to give the enaldehyde concentrations $(\mu \mathrm{M})$ of the plasma samples.

Preparation of blood smears and immunhistological detection of activated $N F-\kappa B p 65$. Whole blood was drawn into syringes containing $3.8 \%$ sodium citrate $(9: 1 ; \mathrm{vol} / \mathrm{vol})$ supplemented with $2 \mathrm{mmol} / \mathrm{l}$ of the antioxidant thioctic acid to avoid method-dependent activation of NF- $\mathrm{BB}$. Blood smears were done immediately and fixed in $4 \%$ paraformaldehyde by standard methods. Immunohistochemistry for cell typing was carried out using CD-3, CD-14 and CD-19 mouse monoclonal antibodies (Pharmingen, Hamburg, Germany). Staining for NFкBp65 was done using a monoclonal antibody (Boehringer Mannheim, Mannheim, Germany), which exclusively recognizes the activated form of NF-KB [29, 35]. Sections were washed in phosphate buffered saline (PBS) pH 7.4, for 5 min before endogenous peroxidase activity was inhibited by treatment with $0.3 \%$ hydrogen peroxide, dissolved in methanol, for $30 \mathrm{~min}$ at room temperature. Blocking was done with $0.6 \%$ normal horse serum for $20 \mathrm{~min}$ at room temperature be- fore monoclonal mouse antibodies (conc.: $0.01 \mu \mathrm{g} / \mu \mathrm{l} ; 60 \mathrm{~min}$; room temperature) were used as primary antibodies. Sections were washed $3 \times 10 \mathrm{~min}$ in PBS, pH 7.4, and then blocking with $0.6 \%$ normal horse serum was repeated for an additional 20 min. Signal detection was carried out with the Vectastain ABC kit (Vector Laboratories Inc., Burlingham, Calif., USA) according to the manufacturer's instructions. Peroxidase activity was visualized with DAB substrate (Vector Laboratories Inc.), after which the sections were counterstained with Hematoxylin (Vector Laboratories Inc.). Control samples for immunostaining were included in all stainings and the primary antibody and its replacement by PBS and matching concentrations of normal horse serum were omitted (data not shown). To visualize the experiments, PBMC were isolated before seeding and fixation on coverslips and stained as described above to ascertain the results obtained in crude blood smears.

Preparation of peripheral blood mononuclear cells (PBMC). Immediately after venipuncture PBMC were separated as described previously $[26,29]$. We carefully loaded $10 \mathrm{ml}$ whole blood, anticoagulated with $3.8 \%$ sodium citrate $(9: 1 ; \mathrm{vol} / \mathrm{vol})$ onto Ficoll Paque Plus gradient (Pharmacia, Freiburg, Germany) and centrifuged for $30 \mathrm{~min}$ at $500 \times g$ (without brakes) at room temperature $[35,36]$. The PBMC containing band was aspirated and the cells were washed three times in PBS, $\mathrm{pH} 7.4$, analysed microscopically and counted independently by two investigators. The cell number was adjusted to $1 \times 10^{6}$ $\mathrm{PBMC} / \mathrm{ml}$. For some experiments PBMC were fractionated by adherence to plasma-coated tissue culture dishes to separate lymphocytes and monocytes as described previously [38]. Where indicated, neutrophil granulocytes were isolated by Polymorphprep (Immuno GmbH, Heidelberg, Germany) as described [38].

Preparation of nuclear proteins. Nuclear extracts were prepared as described before [16, 26, 29]. In brief, $1 \times 10^{6} \mathrm{PBMC}$ were lysed in $400 \mu \mathrm{l}$ icecold buffer A $(10 \mathrm{mmol} / \mathrm{l} \mathrm{HEPES}-$ $\mathrm{KOH}, \mathrm{pH} 7.9$, at $4{ }^{\circ} \mathrm{C}, 1.5 \mathrm{mmol} / \mathrm{l} \mathrm{MgCl}_{2}, 10 \mathrm{mmol} / \mathrm{l} \mathrm{KCl}$, $0.5 \mathrm{mmol} / \mathrm{l} \mathrm{DTT}, 0.2 \mathrm{mmol} / \mathrm{l} \mathrm{PMSF}$ ), incubated on ice and centrifuged for $30 \mathrm{~s}$ at $15000 \mathrm{rpm}$ in a table centrifuge. The supernatant was discarded and the nuclear pellet was resuspended in $100 \mu \mathrm{l}$ icecold buffer B (20 mmol/l HEPES-KOH pH 7.9 at $4{ }^{\circ} \mathrm{C}, 25 \%$ glycerol, $1.5 \mathrm{mmol} / 1 \mathrm{MgCl}_{2}, 420 \mathrm{mmol} / \mathrm{l} \mathrm{NaCl}$, $0.2 \mathrm{mmol} / \mathrm{l} \mathrm{EDTA}, 0.5 \mathrm{mmol} / \mathrm{l} \mathrm{DTT}, 0.2 \mathrm{mmol} / \mathrm{l} \mathrm{PMSF}$ ), incu- 
bated on ice for $20 \mathrm{~min}$ and centrifuged for $2 \mathrm{~min}$ as above. The supernatant containing nuclear proteins was immediately quickfrozen at $-80^{\circ} \mathrm{C}$. Protein concentration was determined according to Bradford using a BCA assay (Pierce, Ill., USA) [40].

Electrophoretic Mobility Shift Assay (EMSA). For EMSA $10 \mu \mathrm{g}$ of nuclear proteins were used. Binding of NF- $\kappa \mathrm{B}$ to $1 \mathrm{ng}$ of $5^{\prime}$-radiolabelled NF- $\mathrm{NB}$ consensus oligonucleotides (5'AGT TGA GGG GAC TTT CCC AGG C-3 '; approximately $50000 \mathrm{cpm}$ [Cerénkov]) was done for $20 \mathrm{~min}$ at room temperature in $10 \mathrm{mmol} / \mathrm{l}$ HEPES, $\mathrm{pH} 7.5,0.5 \mathrm{mmol} / \mathrm{l}$ EDTA, $100 \mathrm{mmol} / 1 \mathrm{KCl}, 2 \mathrm{mmol} / \mathrm{l} \mathrm{DTT}, 2 \%$ glycerol, $4 \%$ Ficoll, $0.25 \% \mathrm{NP}-40,1 \mathrm{mg} / \mathrm{ml}$ bovine serum albumin (BSA) and $0.1 \mu \mathrm{g} / \mu \mathrm{l}$ poly $\mathrm{d} / \mathrm{dC}$ by Pahl's method [40] as described previously $[16,26,29]$. Protein-DNA complexes were separated from the unbound DNA probe by electrophoresis through $5 \%$ native polyacrylamide gels containing $2.5 \%$ glycerol and $0.5 \times$ Tris-Borat-EDTA (TBE) $[16,29,41]$ ). Gels were dried under vacuum and exposed for 48 to $64 \mathrm{~h}$ to Amersham Hyperfilms (Amersham, Braunschweig, Germany) at $-80^{\circ} \mathrm{C}$ with intensifying screens. Specificity of binding was ascertained by competition with a 160-fold molar excess of unlabelled consensus oligonucleotides and by characterisation using specific antibodies for the NF- $\mathrm{BB}$ subunits p65, p50, p52, cRel and relB (all obtained from Santa Cruz, Heidelberg, Germany) as described $[26,41,42]$.

Synthesis of recombinant protein. Recombinant NF-кBp65 (rNF-кBp65) was synthesised according to Melton and Krieg's method [43] as described previously [29, 41] using the T7-promoter of the plasmid Rc-CMV-p65 (P. Baeuerle, Tularik, San Francisco, Calif., USA).

Semiquantitative determination of $N F-\kappa B p 65$ binding activity. To quantitate the NF- $\kappa \mathrm{B}$ signal obtained from isolated PBMC, $\mathrm{rNF}-\kappa \mathrm{Bp} 65$ was included in each EMSA on each gel. 2.5, 5 and $7.5 \mu \mathrm{g}$ rNF- $\mathrm{kBp} 65$ containing lysate were used, the resulting NF- $\kappa \mathrm{B}$ signals were quantitated by densitometry (Biorad) and used to establish a standard curve for each gel [29]. The densitometric value for the NF- $\kappa B$ signal of a given patient was converted into $\mathrm{rNF}-\kappa \mathrm{Bp} 65$ equivalents by using the internal standard curve for rNF-kBp65 [29].

Statistical analysis. Data are expressed as the arithmetric mean \pm standard deviation (SD). The significance of differences was determined using one-way analysis of variance (ANOVA). Correlation between variables were tested using Pearson's correlation analysis. Differences were deemed to be significant when $p$ was less than 0.08 .

\section{Results}

$\mathrm{NF}-\kappa \mathrm{B}$ binding activity in ex vivo isolated PBMC of 33 patients with diabetes mellitus matched for $\mathrm{HbA}_{1 \mathrm{c}}$ and good glycaemic control (Table 1) and ten control subjects without diabetes mellitus was studied using an EMSA-based semiquantitative detection system [29]. Nuclear extracts from PBMC were incubated with radiolabelled oligonucleotides spanning an NF- $\kappa \mathrm{B}$ consensus sequence before being subjected to nondenaturing gel electrophoresis. In addition, binding reactions with three different concentrations
A

\begin{tabular}{|c|c|c|c|c|c|c|}
\hline & 1 & 2 & 3 & 4 & 5 & 6 \\
\hline probe & \multicolumn{3}{|c|}{ standard } & pat.1 & pat.2 & pat.3 \\
\hline albuminuria & & & & - & + & - \\
\hline rNF- $\kappa B$-equivalent & 7.5 & 5 & 2.5 & $<1$ & 9.8 & 2.5 \\
\hline kB & the & & & & & \\
\hline
\end{tabular}

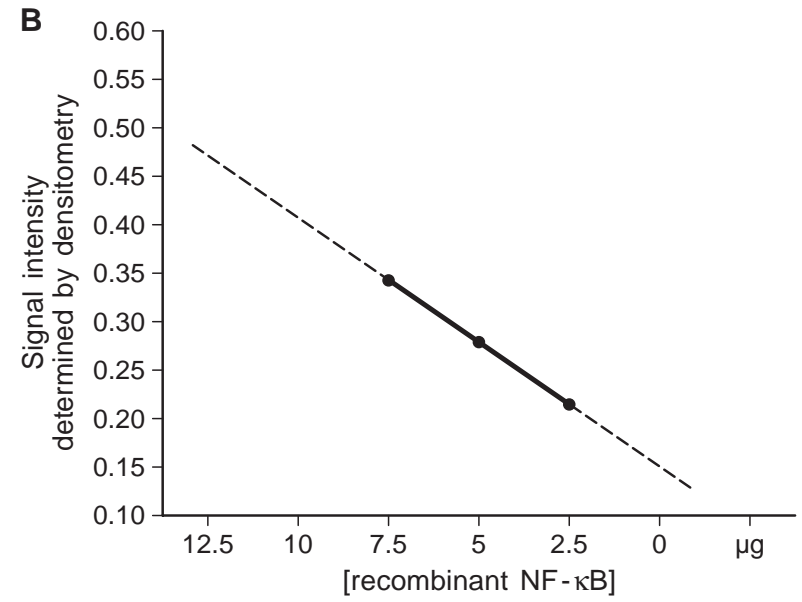

Fig.1A, B. The Electrophoretic Mobility Shift Assay (EMSA) based semiquantitative assay for the determination of NF- $\mathrm{NB}$ binding activity in ex vivo isolated peripheral blood mononuclear cells (PBMC): A EMSA-gel showing the internal standard with $7.5 \mu \mathrm{g}, 5 \mu \mathrm{g}$ and $2.5 \mu \mathrm{g}$ recombinant $\mathrm{NF}-\kappa \mathrm{Bp} 65$ (rNF-кBp65) (lane 1-3) and nuclear extracts derived from three different patients with diabetes mellitus (lane 4-6).The presence or absence of albuminuria is indicated by + and The densitometric intensity determined for each NF- $\kappa \mathrm{B}$ signal is indicated below. B Example of a standard curve obtained for recombinant NF- $\mathrm{\kappa Bp} 65$

of rNF- $\mathrm{kBp} 65$ programmed rabbit reticulocyte lysate $(7.5,5,2.5 \mu \mathrm{g})$ were separated on each gel and served as an internal standard (Fig. 1 a, lane 1-3) [29]. Densitometric evaluation of the signals obtained for the rNF- $\mathrm{kBp} 65$ standards allowed the construction of reproducible standard curves with an intrassay variability of $9 \%$ (Fig. $1 \mathrm{~b}$ ). The intensity of NF- $\kappa \mathrm{B}$ binding activity in ex vivo isolated PBMC of a given probe (Fig. 1 a, lane 4-6) was determined by densitometry and converted into rNF- $\kappa B p 65$ equivalents, thereby providing a semiquantitative assay for the determination of NF- $\mathrm{KB}$ binding activity in a cross-sectional study.

When NF- $\mathrm{KB}$ binding activity in ex vivo isolated PBMC of control subjects without diabetes mellitus was compared with NF- $\kappa \mathrm{B}$ binding activity in PBMC of patients with diabetes mellitus and good glycaemic control, a slight but not significant increase in NF- $\mathrm{KB}$ binding activity was observed (Fig. $2 \mathrm{a} ; p=0.259$ ). 

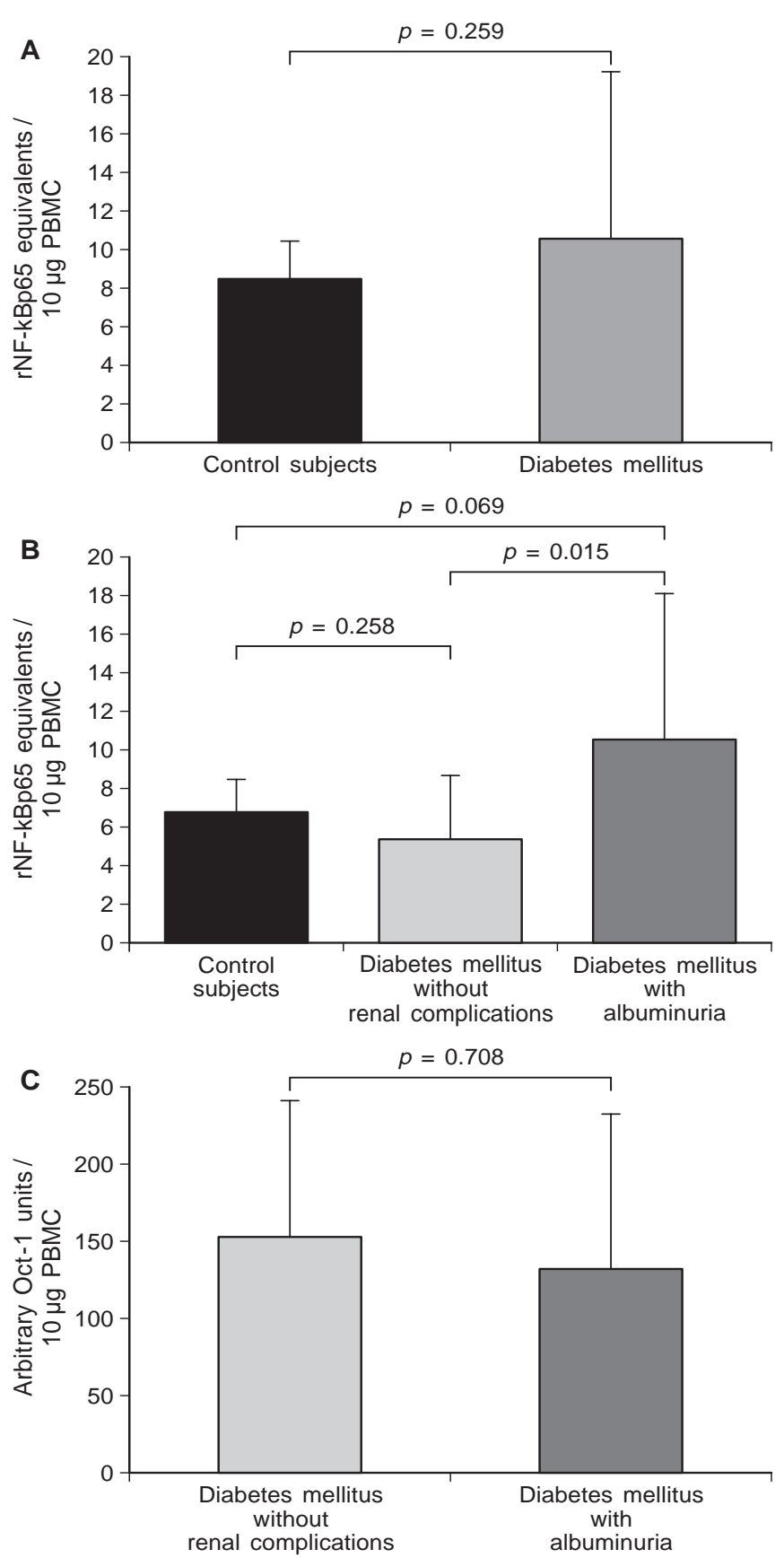

Fig. $2 \mathrm{~A}-\mathrm{C}$. $\mathrm{NF}-\kappa \mathrm{B}$ binding activity in ex vivo isolated PBMC is increased in patients with albuminuria: $10 \mu \mathrm{g}$ nuclear extract of ex vivo isolated $\mathrm{PMBC}$ from 10 healthy control subjects and 33 patients with diabetes mellitus were assayed for NF- $\mathrm{KB}$ binding activity in EMSA. The signal was expressed as recombinant $\mathrm{NF}-\kappa \mathrm{Bp} 65(\mathrm{rNF}-\kappa \mathrm{Bp} 65)$-equivalent by using the internal standard curve for recombinant NF- $\mathrm{Bp} 65(\mathbf{A}, \mathbf{B})$. To control for the quality of the nuclear extract, additional binding reactions were done with the ubiquitious transcription factor Oct-1. Densitometric evaluation of Oct-1 binding is expressed as arbitrary Oct-1 units (c). A NF- $\kappa \mathrm{B}$ binding activity in PBMC of healthy control subjects and diabetic patients matched for $\mathrm{HbA}_{1 \mathrm{c}}$ with good glycaemic control. B NF- $\kappa \mathrm{B}$ binding activity in PBMC of healthy control subjects, diabetic patients matched for $\mathrm{HbA}_{1 \mathrm{c}}$ without renal complications and patients matched for $\mathrm{HbA}_{1 \mathrm{c}}$ with albuminuria. C Oct-1 binding activity in PBMC of diabetic patients matched for $\mathrm{HbA}_{1 \mathrm{c}}$ without renal complications and patients matched for $\mathrm{HbA}_{1 \mathrm{c}}$ with albuminuria

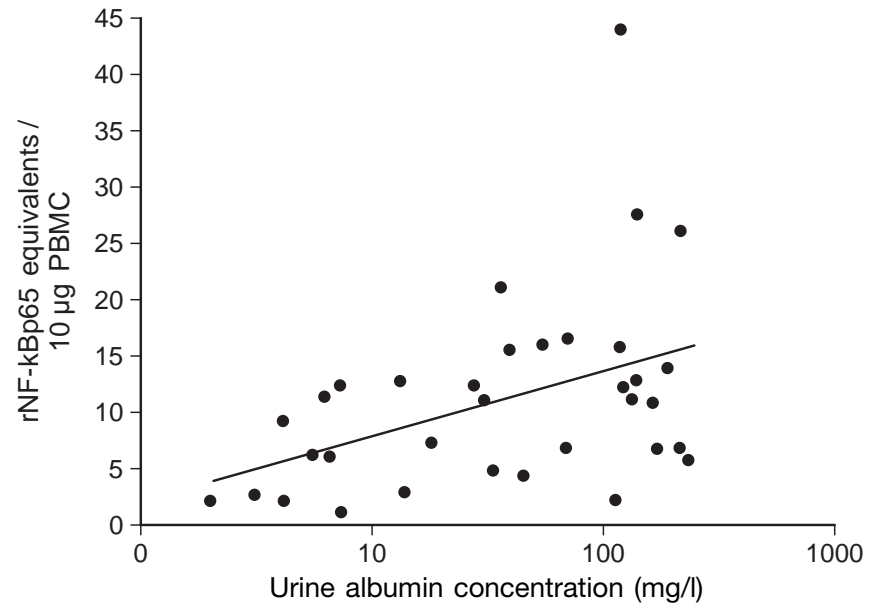

Fig. 3. $\mathrm{NF}-\kappa \mathrm{B}$ binding activity in PBMC correlates with albuminuria: $10 \mu \mathrm{g}$ nuclear extract of PMBC from 33 patients with diabetes mellitus were assayed for $\mathrm{NF}-\kappa \mathrm{B}$ binding activity in EMSA. The signal was expressed as recombinant NF$\kappa B p 65(\mathrm{rNF}-\kappa \mathrm{Bp} 65)$-equivalent by using the internal standard curve for recombinant $\mathrm{NF}-\kappa \mathrm{Bp} 65$ and plotted against urine albumin concentrations $(\mathrm{mg} / 24 \mathrm{~h})(r=0.316 ; p=0.011)$

When all patients with diabetes were divided into two groups based on urine albumin concentration as a sign for diabetic nephropathy (Table 1), no difference was observed between healthy control subjects and diabetic patients matched for $\mathrm{HbA}_{1 \mathrm{c}}$ without renal complications (Fig. 2b, $p=0.258$ ), whereas significantly increased NF- $\kappa \mathrm{B}$ activation was found in PBMC of diabetic patients with albuminuria (Fig. $2 \mathrm{~b}, p=0.069$ vs control subjects; $p=0.015$ vs patients without renal complications). Since nuclear extracts of PBMC derived from patients without renal complications and from patients with albuminuria showed a constant activity for the transcription factor Oct-1 (Fig. 2c; $p=0.708$ ), it could be almost excluded, that the observed changes in NF- $\kappa \mathrm{B}$ binding activity were related to methodological variances. The data, therefore, indicate that albuminuria is associated with increased NF- $\kappa \mathrm{B}$ activation in ex vivo isolated PBMC, even in the absence of hyperglycaemia. The extent of mononuclear NF- $\kappa \mathrm{B}$ binding activity in ex vivo isolated $\mathrm{PBMC}$ significantly correlated with the severity of albuminuria (Fig. 3; Pearson's coefficient $r=0.316, p=0.011$ ). The correlation did not significantly differ in patients with nephropathy alone and patients with nephropathy in the presence of retinopathy or neuropathy or both (data not shown). No correlation was observed with age, duration of disease, BMI, cholesterol and blood pressure (Table 3). In all samples studied, proteins binding to the $\mathrm{NF}-\kappa \mathrm{B}$ consensus motif were characterised as NF$\kappa \mathrm{B}(\mathrm{p} 50 / \mathrm{p} 65)$ by supershifting and competition experiments (data not shown).

Isolation of PBMC by Ficoll Paque gradient resulted in enrichment of mononuclear cells with less 
Table 3. Correlation of PBMC NF- $\kappa \mathrm{B}$ binding activity with other variables predicting diabetes mellitus

\begin{tabular}{lll}
\hline & $\mathrm{R}$-square & $p$-value \\
\hline Age & $\mathrm{R}=0.0267$ & 0.397 \\
Duration of disease & $\mathrm{R}=0.0015$ & 0.8343 \\
$\mathrm{HbA}_{1 \mathrm{c}}$ & $\mathrm{R}=0.0002$ & 0.9493 \\
$\mathrm{BMI}\left(\mathrm{kg} / \mathrm{m}^{2}\right)$ & $\mathrm{R}=0.0419$ & 0.2694 \\
Cholesterol $(\mathrm{mg} / \mathrm{dl})$ & $\mathrm{R}=0.0246$ & 0.4164 \\
Systolic blood pressure & $\mathrm{R}=0.0200$ & 0.4302 \\
Diastolic blood pressure & $\mathrm{R}=0.0282$ & 0.3840 \\
\hline
\end{tabular}

than $3 \%$ contamination of neutrophil granulocytes $[29,35,36]$. Cell typing with CD-14, CD-19 and CD3 antibodies showed that the enriched PBMC fractions contained approximately equimolar amounts of monocytes, B-lymphocytes and T-lymphocytes in all samples tested (Fig. 4). A moderate but statistically not significant switch towards B-lymphocytes was observed in some PBMC fractions of patients with albuminuria (Fig. 4, $p=0.241$ ). To define which cell type contributed to the albuminuria dependent NF$\kappa \mathrm{B}$ activation, PBMC fractions were separated into lymphocytes and monocytes [29, 37]. Both fractions were shown to have a strong induction of NF- $\mathrm{BB}$ binding activity in PBMC of patients with albuminuria (Fig. 4). Isolated granulocytes showed prominent

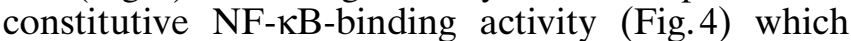
was slightly more pronounced in patients with albuminuria (Fig. 4). Since granulocytes contributed less than $3 \%$ to all cells in the PBMC preparation, this weak induction did probably not contribute greatly to the inducible NF- $\mathrm{KB}$ signal observed in lymphocytes and monocytes.

To exclude that the NF- $\kappa \mathrm{B}$ binding activity determined in EMSA of ex vivo isolated PBMC was caused by cellular activation during the isolation procedure, blood from 14 patients was drawn into syringes containing $3.8 \%$ sodium citrate $(9: 1 ; \mathrm{vol} / \mathrm{vol})$ supplemented with $2 \mathrm{mmol} / \mathrm{l}$ thioctic acid ( $\alpha$-lipoic acid), which previously has been shown to inhibit $\mathrm{NF}-\mathrm{\kappa B}$ activation in vitro and in vivo $[16,29,30,31]$. After venipuncture blood smears were prepared, fixed immediately and stained with an antibody reacting exclusively with activated NF- $\kappa B p 65$ [29]. Positivity for activated NF- $\mathrm{KBp} 65$ was identified by a dark brown staining within the cells [29, 34]; accordingly only cells with NF- $\kappa B p 65$ staining within the cell were counted as positive [29, 34]. PBMC showing strong activation of NF- $\mathrm{\kappa B}$ are marked with arrows. In patients without renal complications mononuclear activation of NF- $\mathrm{KBp} 65$ was less as reflected by an average of $36 \%$ positively stained cells (Fig.5a left, Fig. 5 b). In contrast, almost all PBMC of patients with albuminuria showed strong reactivity with antibodies for activated NF- $\mathrm{KBp} 65$ and an average of $64 \%$ PBMC stained positive (Fig. 5 a right, Fig. 5 b). The difference in staining was statistically significant

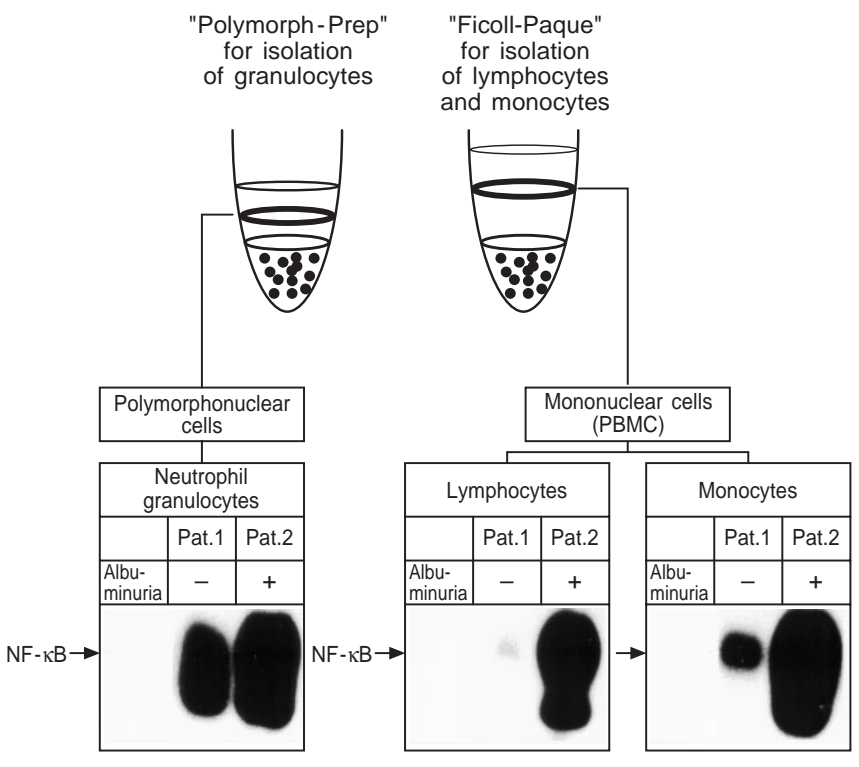

Typing of cells present in PBMC-pellets enriched by "Ficoll-Paque"

\begin{tabular}{|l|c|c|}
\hline & $\begin{array}{c}\text { Without renal } \\
\text { complications } \\
\text { (pat.1) }\end{array}$ & $\begin{array}{c}\text { With albuminuria } \\
\text { (pat.2) }\end{array}$ \\
\hline T-lymphocytes & $37 \%$ & $32 \%$ \\
\hline B-lymphocytes & $26 \%$ & $34 \%$ \\
\hline Monocytes & $37 \%$ & $34 \%$ \\
\hline
\end{tabular}

Fig. 4. Lymphocytes and monocytes contribute to increased $\mathrm{NF}-\kappa \mathrm{B}$ activation in ex vivo isolated PBMC of patients with albuminuria: granulocytes and mononuclear cells (PBMC) were isolated from two representative patients matched for $\mathrm{HbA}_{1 \mathrm{c}}$ without renal complications and with albuminuria. PBMC were further fractionated by adherence to plasma-coated tissue culture dishes to separate lymphocytes and monocytes. Nuclear extracts were prepared and assayed in EMSA to determine NF- $\kappa \mathrm{B}$ binding activity in each of the cell fractions. Radioactive labelled oligonucleotides, spanning the consensus $\mathrm{NF}-\kappa \mathrm{B}-$ recognition motif, were incubated with equal amounts of nuclear extracts and complexes were separated onto nondenaturing $5 \%$ PAA gels. The position of NF- $\kappa B$ is indicated by an arrow. Results of immunhistological typing of cells present in the PBMC pellet using CD-19, CD-3 and CD-14 antibodies are shown below

$(p<0.003)$ and confirmed the difference for NF- $\mathrm{kB}$ binding activity observed in EMSA.

The antioxidant thioctic acid ( $\alpha$-lipoic acid) has been shown to reduce hyperglycaemia dependent $\mathrm{NF}-\kappa \mathrm{B}$ binding activity in ex vivo isolated PBMC [29]. To determine whether thioctic acid can also reduce albuminuria mediated $\mathrm{NF}-\kappa \mathrm{B}$ activation, nine patients with diabetic nephropathy selected at random were treated orally with $600 \mathrm{mg}$ thioctic acid per day for 3 days. Before and after intervention blood samples were collected, PBMC were isolated and $\mathrm{NF}-\kappa \mathrm{B}$ binding activity was determined as above (Table 2). In parallel, enaldehydes (MDA + 4-HNE) which are said to be plasmatic markers for oxidative stress [44], were measured in plasma samples from the same donor [29] before and after thioctic acid 
A

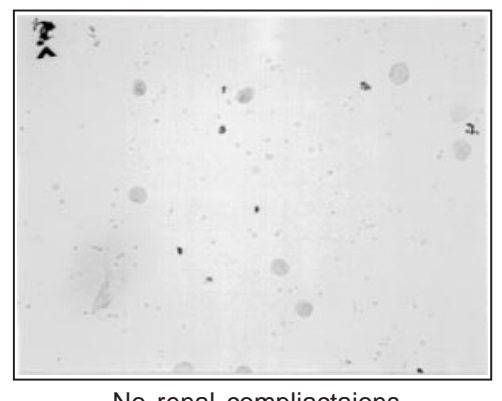

No renal compliactaions

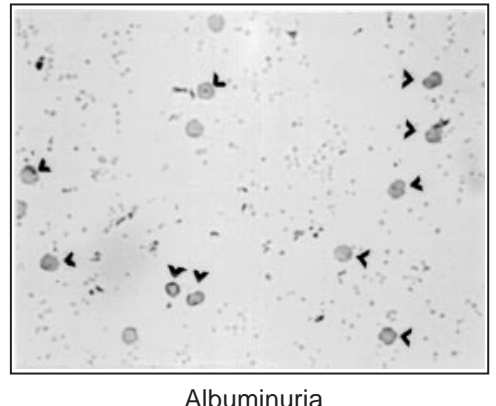

Albuminuria

Fig. 5A, B. Activation of NF- $\mathrm{ABp} 65$ is increased in PBMC of patients with albuminuria: A Immunhistochemistry for active $\mathrm{NF}-\kappa \mathrm{Bp} 65$ in PBMC of two representative patients without renal complications (top) and with albuminuria (bottom): PBMC and granulocytes fractions were collected (see Materials and methods), combined and seeded onto coverslips, before immunohistochemistry was done using a monoclonal antibody that exclusively reacts with activated NF- $\mathrm{KBp} 65$. Positivity for $\mathrm{NF}-\kappa \mathrm{Bp} 65$ is indicated by dark brown color; positive PBMC are indicated by arrows. B Compared with patients without renal complications, staining for active NF- $\kappa B p 65$ was significantly increased in PBMC of patients with albuminuria $(p=0.003)$

supplementation (Table 2). Treatment of 3 days with thioctic acid decreased PBMC derived NF- $\kappa \mathrm{B}$ binding activity in all samples tested (Fig. 6a). The average NF- $\mathrm{KB}$ binding activity before thioctic acid supplementation equalled $16 \mathrm{rNF}-\kappa \mathrm{Bp} 65$ equivalents and was reduced to $9 \mathrm{rNF}-\kappa \mathrm{Bp} 65$ equivalents after thioctic acid therapy ( $p=0.031$, Fig. 6 b, Table 2$)$. Before thioctic acid treatment the slope indicating the rise in NF- $\mathrm{\kappa B}$ binding activity with increasing albuminuria was steeper (Fig. 6c) than after thioctic acid supplementation (Fig. 6c). Pearson's correlation for $\mathrm{NF}-\mathrm{\kappa B}$ binding activity and albuminuria was stronger before (Pearson's coefficient $r=0.365, p=0.001$ ) than after (Pearson's coefficient $r=0.194, \quad p=$ 0.0005) supplementation with thioctic acid and the difference in NF- $\kappa \mathrm{B}$ binding activity in both groups was statistically significant $(p=0.031)$. The thioctic acid mediated decrease in PBMC NF- $\mathrm{\kappa B}$ binding activity was paralleled by a $48 \%$ reduction in plasma e-
B

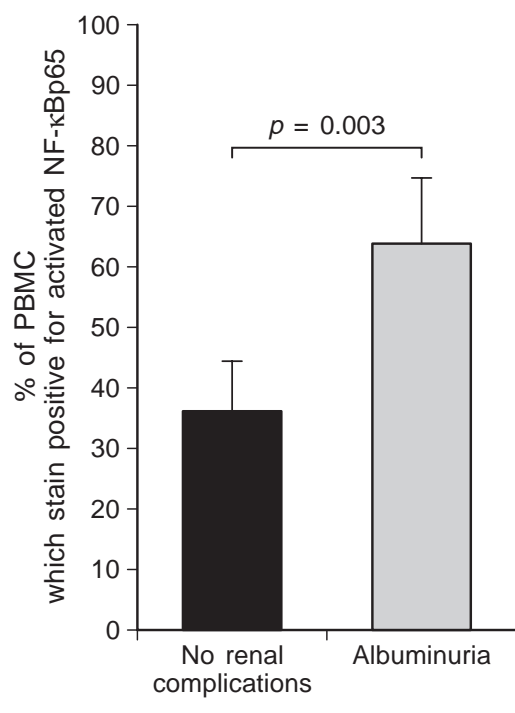

naldehydes (Fig.6d), thereby indicating that albuminuria associated NF- $\kappa$ B activation was, at least in part, dependent on oxidative stress.

Plasma thrombomodulin has been described as marker of endothelial activation and endothelial damage which correlates with diabetic microvascular disease [34, 45] and albuminuria [46, 47]. Raised plasma thrombomodulin concentrations have been reported in patients with increased oxidant injury, tubular damage and proteinuria [48]. Accordingly, thrombomodulin plasma concentrations correlated positively with albuminuria (Pearson's coefficient $r=$ 0.341 , data not shown) and NF- $\kappa \mathrm{B}$ binding activity determined in PBMC of 20 of our study subjects (Pearson's coefficient $r=0.337$; Fig. 7).

\section{Discussion}

The pathogenesis of cellular, structural and functional abnormalities in diabetic nephropathy is a multifactorial process associated with persistent hyperglycaemia [49], AGE-formation and deposition [50, 51], hyperlipidaemia [52] and hyperhomocysteinaemia [47]. There is growing evidence, however, that oxidative stress might represent a major common basis for the pathogenesis of renal complications [6-9] by possibly disrupting cellular functions by activation of the transcription factor NF- $\mathrm{KB}$ and subsequent coordinated expression of gene products as leucocyte adhesion molecules, cytokines, renal eNOS, MCP-1, endothelin-1 and tissue factor [12, 14-20], all of which are said to contribute to late diabetic complications. Up to date, however, a direct proof of oxidative stress 
A

\begin{tabular}{|c|c|c|c|c|c|c|c|c|c|}
\hline & 1 & 2 & 3 & 4 & 5 & 6 & 7 & 8 & 9 \\
\hline Probe & & \multicolumn{2}{|l|}{ Standard } & \multicolumn{2}{|c|}{ Patient 1} & \multicolumn{2}{|c|}{ Patient 2} & \multicolumn{2}{|c|}{ Patient 3} \\
\hline Thioctic acid & & & & - & + & - & + & - & + \\
\hline rNF-kB-equivalent & 2.5 & 5 & 7.5 & & & & & & \\
\hline $\mathrm{NF}-\mathrm{kB} \rightarrow$ & est & eas & & & & & & & \\
\hline
\end{tabular}

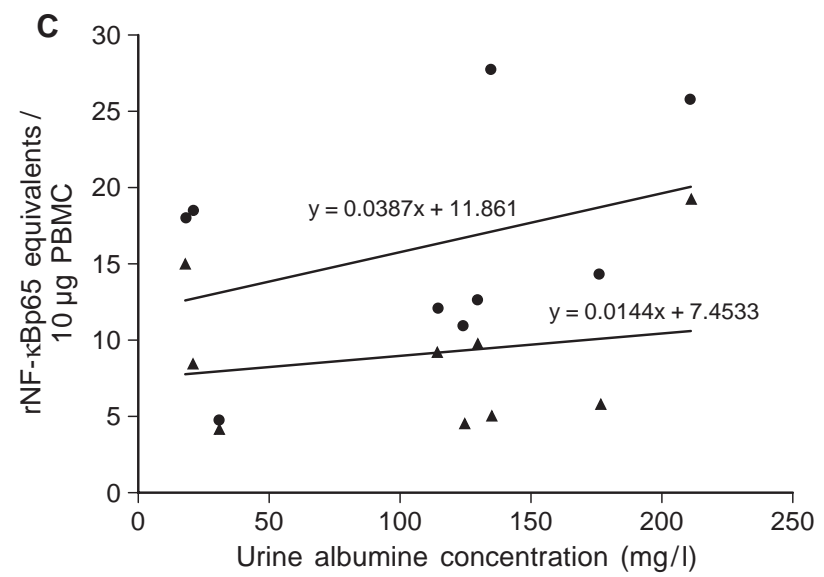

B
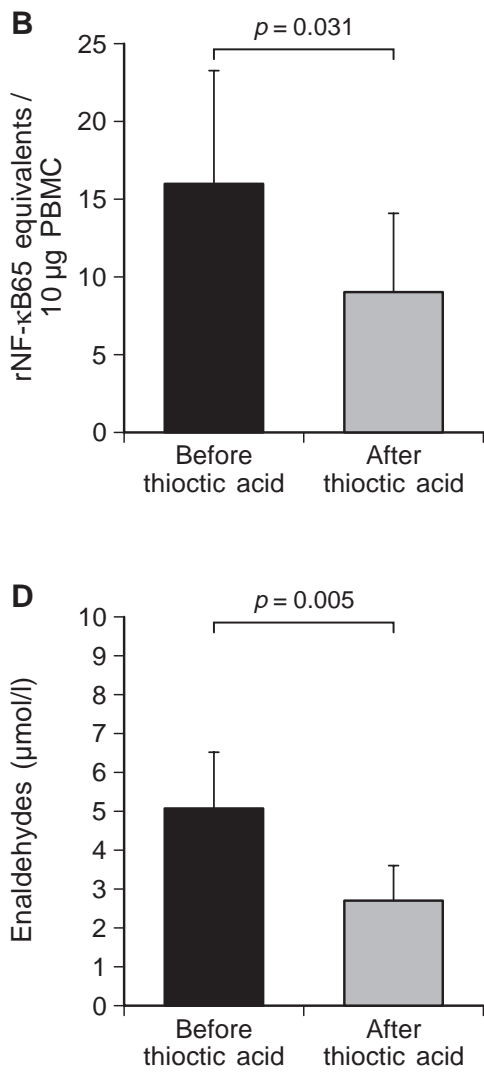

Fig. 6A-D. NF- $\kappa B$ binding activity in PBMC of patients with albuminuria decreases after treatment with thioctic acid: nine patients selected randomly and matched for $\mathrm{HbA}_{1 \mathrm{c}}$ (Table 2) with diabetic nephropathy received $600 \mathrm{mg}$ of the antioxidant thioctic acid per day orally for 3 days. NF- $\mathrm{KB}$ binding activity of ex vivo isolated PBMC (A-C) and plasmatic markers of oxidative stress $(\mathbf{D})$ were determined in all patients before and after thioctic acid supplementation. A NF- $\kappa \mathrm{B}$ activation in ex vivo isolated $\mathrm{PBMC}$ of three representative patients before and after thioctic acid supplementation. B NF- $\mathrm{B}$ binding activity determined for all patients in EMSA was expressed as recombinant NF- $\kappa \mathrm{Bp} 65(\mathrm{rNF}-\kappa \mathrm{Bp} 65)$-equivalent by using the internal standard curve for recombinant NF- $\kappa$ Bp65. The average $\mathrm{NF}-\kappa \mathrm{B}$ binding activity before thioctic acid supplementation equalled $16 \mathrm{rNF}-\kappa \mathrm{Bp} 65$ equivalents and was reduced to 9 rNF- $\kappa$ Bp65 equivalents after thioctic acid supplementation. C Correlation of NF- $\kappa \mathrm{B}$ binding activity with urine albumine concentrations before $(\boldsymbol{O}, r=0.365, p=0.001)$ and after $(\boldsymbol{\Delta}$, $r=0.194, p=0.0005)$ thioctic acid supplementation $(p=$ 0.031). D Plasmatic markers for oxidative stress (MDA and 4-HNE) were determined in plasma samples of all patients before and after thioctic acid supplementation and are expressed as enaldehyde concentration $(\mu \mathrm{mol} / \mathrm{l})$

dependent $\mathrm{NF}-\kappa \mathrm{B}$ activation in patients with diabetic nephropathy is not known.

To define the extent of NF- $\mathrm{KB}$ activation in patients with diabetic nephropathy, we used an EMSA based semiquantitative detection system [29] which allowed the determination of NF- $\kappa \mathrm{B}$ binding activity in ex vivo isolated PBMC, which - in contrast to kid- ney biopsies - could be easily obtained during the routine examination of diabetic patients. Compared with patients matched for $\mathrm{HbA}_{1 \mathrm{c}}$ without renal complications, patients with diabetic nephropathy showed a significant increase in NF- $\kappa \mathrm{B}$ activation (Fig. 1-3, 6). No correlation of NF- $\mathrm{NB}$ was observed with other variables predicting diabetes mellitus such as age, duration of disease, BMI, total cholesterol or blood pressure (Table 3); however, the patient group in this study is too small to carry out a careful multivariate analysis and larger studies will be required to define whether additional variables might influence increased NF- $\mathrm{NB}$ activation observed in PBMC of patients with albuminuria.

The correlation of NF- $\kappa B$ with albuminuria was not significantly changed when nephropathy was accompanied by other late diabetic complications such as retinopathy or neuropathy. To evaluate the relative contribution of other late diabetic complications, again much larger studies allowing for multivariate analysis are needed.

To exclude that the EMSA based detection of NF$\kappa \mathrm{B}$ signals in ex vivo isolated PBMC was in part derived from cellular activation during the isolation procedure, peripheral blood smears were prepared and fixed immediately after venipuncture and before staining with an antibody exclusively recognizing activated NF- $\mathrm{KBp} 65$ [29, 34]. These conditions almost excluded experimental activation of NF- $\mathrm{\kappa B}$ and immunoreactivity was supposed to reflect the in vivo ac- 


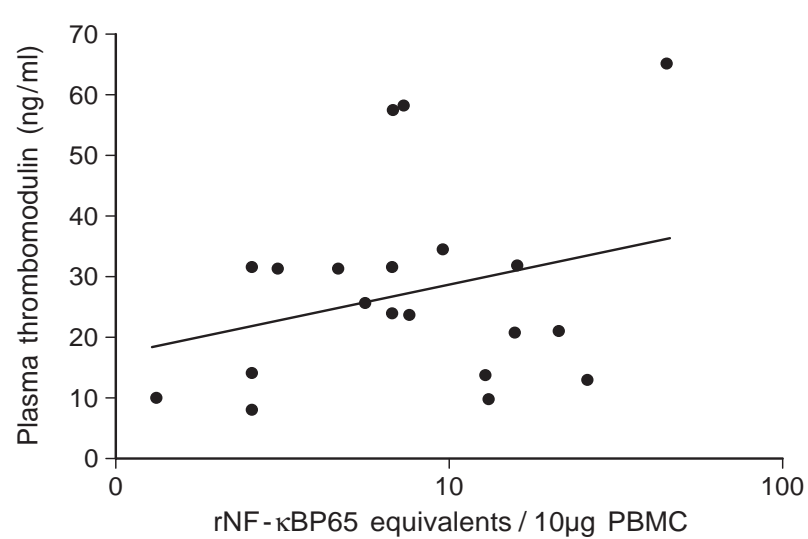

Fig. 7. Plasma thrombomodulin levels correlate NF- $\kappa B$ binding activity: correlation of thrombomodulin plasma concentrations ( $\mathrm{ng} / \mathrm{ml}$ ) with $\mathrm{NF}-\kappa \mathrm{B}$ binding activity (expressed as $\mu \mathrm{g}$ rNF- $\kappa$ Bp65 equivalents per $10 \mu \mathrm{g}$ nuclear extract of PBMC) in 20 patients with diabetes mellitus $(r=0.337 ; p=0.05)$

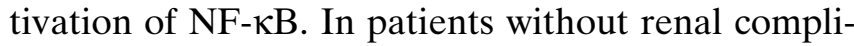
cations we observed only occasional exactivated NFкBp65 staining, while mononuclear cells from patients with albuminuria showed increased staining

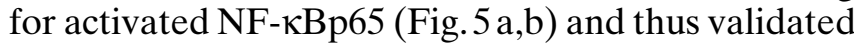
the results for NF- $\mathrm{\kappa B}$ binding activity obtained in EMSA (Fig. 1-3).

Increased NF- $\kappa \mathrm{B}$ activation has previously been described in mononuclear cells in the arteriosclerotic plaque [34] and thus, might in part increase the risk for coronary heart disease and arteriosclerosis observed in patients with diabetic nephropathy [49]. In addition, the correlation of thrombomodulin plasma concentrations with albuminuria and NF- $\kappa B$ binding activity (Fig. 7) indicates a parallel activation or damage of endothelial cells. To date it is not known whether NF- $\mathrm{kB}$ controlled genes in monocytes and macrophages participate in mediating endothelial cell dysfunction. An oxidative stress dependent general NF- $\kappa$ B activation that affects both mononuclear and endothelial cells might promote further arteriosclerosis since NF- $\mathrm{KB}$ controlled endothelial genes include adhesion molecules [12] and the procoagulant tissue factor [25]. Increased plasma concentrations of vascular cell adhesion molecule-1 (VCAM-1) and tissue factor have been reported in patients with albuminuria and microvascular disease [53-55] and increased expression of monocyte procoagulant activity has been shown in Type I diabetic patients with microalbuminuria [56].

Increased NF- $\mathrm{NB}$-activation in monocytes and macrophages might also promote infiltration of macrophages in glomeruli and thus contribute to lipid-induced nephrotoxicity in diabetic nephropathy [57]. $\mathrm{NF}-\kappa \mathrm{B}$ activation in tissue macrophages might change their ability to effectively degrade and eliminate AGE-macromolecules [50] and therefore support AGE-deposition in renal tissues. The biological func- tion of increased NF- $\kappa \mathrm{B}$ binding activity in PBMC of patients with diabetic nephropathy, however, is still not known and further studies will be required.

Recently macrophages from NF-кBp65 deficient mice were shown to be sensitive to TNF $\alpha$ induced cytotoxicity and apoptosis [58]. Anti-apoptotic effects of NF- $\mathrm{KB}$ activation in response to endogenous, exogenous, genotoxic, inflammatory and stress-inducing conditions have also been described in other cell types [59]. Thus, NF- $\mathrm{KB}$ activation in PBMC of patients with diabetic nephropathy might represent a mechanism to protect monocytes and macrophages from apoptosis, which in turn causes activation of anti-apoptotic genes and the expression of gene products involved in the pathogenesis of late diabetic complications.

To downregulate the excessive NF- $\kappa \mathrm{B}$ activation observed in PBMC of patients with diabetic nephropathy it could be difficult to find substances which do not completely inhibit NF- $\mathrm{KB}$ and thereby promote apoptosis. In the treatment of inflammatory diseases, glucocorticoids and salicylates have been proven to

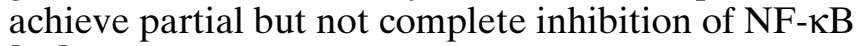
[59]. Thioctic acid is another substance which has effectively reduced but not completely suppressed NF$\kappa \mathrm{B}$ activation in vitro $[16,30]$. This study shows that the antioxidant thioctic acid reduces, but not eliminates, NF- $\kappa \mathrm{B}$ activation in vivo in PBMC of patients with diabetic nephropathy (Fig.6). Thus, thioctic acid might be suitable to prevent NF- $\kappa \mathrm{B}$ dependent cellular changes towards renal end-stage disease, while still allowing protection from cytotoxicity and apoptosis. Whether treatment with thioctic acid might also be suitable to reduce albuminuria in Type I diabetes patients, is currently under investigation.

Acknowledgements. The authors like to thank Dr. P.A. Baeuerle (Tularik Inc., San Francisco, Calif., USA) for providing the NF-кBp65-plasmid Rc-CMV-p65. This work was in part supported by grants from the Deutsche Forschungsgemeinschaft and the University of Heidelberg, Germany. P. P. Nawroth did this study during tenure of a Schilling-professorship.

\section{References}

1. Baynes JW (1991) Role of oxidative stress in development of complications in diabetes. Diabetes 40: 405-412

2. Nourooz-Zadeh J, Rahimi A, Tajaddini-Sarmadi J et al. (1997) Relationship between plasma measures of oxidative stress and metabolic control in non-insulin-dependent diabetes mellitus. Diabetologia 40: 647-654

3. Godin DV, Wohaieb SA, Garnett ME, Goumeniouk AD (1988) Antioxidant enzyme alterations in experimental and clinical diabetes. Mol Cell Biochem 84: 223-231

4. Giugliano D, Ceriello A, Paolisso G (1995) Diabetes mellitus, hypertension, and cardiovascular disease: which role for oxidative stress? Metabolism 44: 363-368

5. Rema M, Mohan V, Bhaskar A, Shanmugasundaram KR (1995) Does oxidant stress play a role in diabetic retinopathy? Indian J Opthalmol 43: 17-21 
6. Salahudeen AK, Kanji V, Reckelhoff JF, Schmidt AM (1997) Pathogenesis of diabetic nephropathy: a radical approach. Nephrol Dial Transplant 12: 664-668

7. Ha H, Kim KH (1995) Role of oxidative stress in the development of diabetic nephropathy. Kidney Int Suppl 51:S18-21

8. Ha H, Lee SH, Kim KH (1997) Effects of rebamipide in a model of experimental diabetes and on the synthesis of transforming growth factor-beta and fibronectin, and lipid peroxidation induced by high glucose in cultured mesangial cells. J Pharmacol Exp Ther 281: 1457-1462

9. Aoki Y, Yazaki K, Shirotori K et al. (1993) Stiffening of connective tissue in elderly diabetic patients: relevance to diabetic nephropathy and oxidative stress. Diabetologia 36: 79-83

10. Kakkar R, Mantha SV, Radhi J, Prasad K, Kalra J (1997) Antioxidant defense system in diabetic kidney: a time course study. Life Sci 60: 667-679

11. Schlöndorff D (1996) Roles of the mesangium in glomerular function. Kidney Int 49: 1583-1585

12. Collins T (1993) Endothelial nuclear factor-kappa B and the initiation of the atherosclerotic lesion. Lab Invest 68 : 499-508

13. Guijarro C, Kim Y, Kasiske BL et al. (1997) Central role of the transcription factor nuclear factor-kappa B in mesangial cell production of chemokines. Contrib Nephrol 120: 210-218

14. Barnes PJ, Karin M (1997) Nuclear Factor- $\kappa B$ - a pivotal transcription factor in chronic inflammatory diseases. N Engl J Med 336: 1066-1071

15. Schmidt AM, Hori O, Chen JX et al. (1995) Advanced glycation endproducts interacting with their endothelial receptor induce expression of vascular cell adhesion molecule-1 (VCAM-1) in cultured human endothelial cells and in mice. J Clin Invest 96: 1395-1403

16. Bierhaus A, Chevion S, Chevion M et al. (1997) Advanced glycation endproducts (AGEs) induced activation of NF$\kappa \mathrm{B}$ is suppressed by $\alpha$-lipoic acid in cultured endothelial cells. Diabetes 46: 1481-1490

17. Schmidt AM, Yan SD, Stern DM (1995) The dark side of glucose. Nat Med 1: 1002-1004

18. Quehenberger P, Bierhaus A, Fasching P et al. (1997) Induction of endothelin-1 through erythrocytes of patients with diabetes mellitus. Thromb Haemost 77 [Suppl 1]:458 (Abstract)

19. Amoah-Apraku B, Chandler LJ, Harrison JK, Tang SS, Ingelfinger JR, Guzman NJ (1995) NF- $\kappa B$ and transcriptional control of renal epithelial-inducible nitric oxide synthase. Kidney Int 48: 674-682

20. Rovin BH, Dickerson JA, Tan LC, Hebert CA (1995) Activation of nuclear factor- $\kappa \mathrm{B}$ correlates with MCP-1 expression by human mesangial cells. Kidney Int 48: $1263-1271$

21. Combe C, Burton CJ, Dufourco P (1997) Hypoxia induces intercellular adhesion molecule-1 on cultured human tubular cells. Kidney Int 51: 1703-1709

22. Khachigan LM, Collins T, Fries JW (1995) Nuclear factorkappa B mediates induction of vascular cell adhesion molecules in glomerular mesangial cells. Biochem Biophys Res Commun 206: 462-467

23. Satriano J, Schlöndorff D (1994) Activation and attenuation of transcription factor $\mathrm{NF}-\kappa \mathrm{B}$ in mouse glomerular mesangial cells in response to tumor necrosis factor- $\alpha$, immunglobulin $G$ and adenosine $3{ }^{\prime} 5^{\prime}$-cyclic monophosphate. J Clin Invest 94: 1629-1636

24. Bierhaus A, Hofmann MA, Ziegler R, Nawroth PP (1998) The AGE/RAGE pathway in vascular disease and diabetes mellitus. Part I: The AGE-concept. Cardiovasc Res 37: 586-600

25. Bierhaus A, Illmer T, Kasper M et al. (1997) Advanced glycation endproducts (AGEs) mediated induction of tissue factor in cultured endothelial cells is dependent on RAGE. Circulation 96: 2262-2271

26. Böhrer H, Qiu F, Zimmermann T et al. (1997) Role of NFkB in the mortality of sepsis. J Clin Invest 100: 974-982

27. Douvedevani A, Abramson O, Tamir A, Konforty A, Isakov N, Chaimovitz C (1995) Commercial dialysate inhibits $\mathrm{TNF} \alpha \mathrm{mRNA}$ expression and NF- $\kappa \mathrm{B}$ DNA-binding activity in LPS-stimulated macrophages. Kidney Int 47: $1537-1545$

28. Bierhaus A, Kasper M, Langer S et al. (1997) Activation of the transcription factor NF- $\mathrm{\kappa B}$ in kidneys of diabetic rats. Exp Clin Endocrinol Diabetes 105 [Suppl 1]:15 (Abstract)

29. Hofmann MA, Schiekofer S, Kanitz M et al. (1998) Insufficient glycaemic control increases NF- $\kappa \mathrm{B}$ binding activity in peripheral blood mononuclear cells isolated from patients with type 1 diabetes. Diabetes Care 21: 1-7

30. Packer L (1993) The role of anti-oxidative treatment of diabetes mellitus. Diabetologia 36: 1212-1213

31. Packer L, Witt EH, Tritschler HJ (1995) Alpha-Lipoic acid as a biological antioxidant. Free Radical Biology \& Medicine 19: 227-250

32. Suzuki YJ, Aggarwal BB, Packer L (1992) Alpha-lipoic acid is a potent inhibitor of NF-kappa B activation in human T cells. Biochem Biophys Res Commun 189: 1709-1715

33. Gabat S, Keller C, Kempe H-P et al. (1996) Plasma thrombomodulin: a marker of vascular complications in diabetes. Vasa 25: 233-241

34. Brand K, Page S, Rogler G et al. (1996) Activated transcripton factor-kappa $\mathrm{B}$ is present in the atherosclerotic lesion. J Clin Invest 97: 1715-1722

35. Rothbarth HP, Hendriks-Sturkenboom I, Ploem J (1976) Identification of monocytes in suspension of mononuclear cells. Blood 48: 139-147

36. Pertoft H, Johnsson A, Wärmegard B, Seljelid R (1980) Separation of human monocytes on density gradients of percoll. J Immunol Methods 33: 221-229

37. Hölschermann H, Dürfeld F, Maus U et al. (1997) Cyclosporine A inhibits tissue factor expression in monocytes/macrophages. Blood 88: 3837-3845

38. Hemmer CJ, Bierhaus A, v. Riedesel J et al. (1994): Elevated thrombomodulin plasma levels as a result of endothelial involvement in plasmodium falciparum malaria. Thromb Haemost 72: 457-464

39. Bradford MM (1976) A rapid and sensitive method for the quantitation of microgramm quantities of protein utilizing the principle of protein dye binding. Anal Biochem 72: 248-254

40. Pahl HL, Baeuerle PA (1995) Expression of influenza virus hemagglutinin activates the transcription factor NFkB. J Virol 69: 1480-1484

41. Bierhaus A, Zhang Y, Deng Y et al. (1995) Mechanism of the TNF $\alpha$ mediated induction of endothelial tissue factor. J Biol Chem 270: 26419-26432

42. Bierhaus A, Zhang Y, Quehenberger P et al. (1997) The dietary pigment curcumin reduces endothelial tissue factor gene expression by inhibiting binding of AP-1 to the DNA and activation of NF- $\mathrm{KB}$. Thromb Haemost 77: 772-782

43. Melton DA, Krieg PA, Rabdaliati MR, Maniatis T, Zinn K, Green MR (1984) Efficient synthesis of biologically active RNA and RNA hybridisation probes from plasmids containing a bacteriophage SP6 promotor. Nucleic Acids Res 12: 7035-7056 
44. Janero DR (1990) Malonaldehyde and thiobarbituric acidreactivity as diagnostic indices of lipid peroxidation and peroxidative tissue injury. Free Radic Biol Med 9: 515-540

45. Sernau T, Wilhelm O, Seyfert U et al. (1995) Thrombomodulin ist ein Marker für mikrovaskuläre, aber nicht für makrovaskuläre Endothelschädigung. Vasa 24: 347-353

46. Rinno H, Kuramoto T, Iijima T, Yagame M, Tomino Y (1996) Measurement of soluble thrombomodulin in sera from various clinical stages of diabetic nephropathy. J Clin Lab Anal 10: 119-124

47. Hofmann MA, Kohl B, Zumbach MS et al. (1997) Hyperhomocyst(e)inemia and endothelial dysfunction in IDDM. Diabetes Care 20: 1880-1887

48. Yaqoob M, Patrick AW, McClelland P et al. (1993) Relationsship between markers of endothelial dysfunction, oxidant injury and tubular damage in patients with insulin-dependent diabetes mellitus. Clin Sci (Colch) 85: 557-562

49. The Diabetes Control and Complication Trial Research Group (1993) The effect of intensive treatment of diabetes on the development and progression of long term complications in insulin dependent diabetes mellitus. N Engl J Med 329: 977-986

50. Vlassara H (1997) Pathogenesis of diabetic nephropathy, advanced glycation and new therapy. Med Klin 92 [Suppl 1]:29-34

51. Vlassara H (1996) Protein glycation in the kidney: Role in diabetes and aging. Kidney Int 49: 1795-1804
52. Saito T (1997) Abnormal lipid metabolism and renal disorder. Tohoku J Exp Med 181: 321-337

53. Biesenbach G, Janko O, Zazgornik J (1994) Similar rate of progression in the predialysis phase in type I and type II diabetes mellitus. Nephrol Dial Transplant 9: 1097-1102

54. Schmidt AM, Crandall J, Hori O, Cao R, Lakatta E (1996) Elevated plasma levels of vascular cell adhesion molecule1 (VCAM-1) in diabetic patients with microalbuminuria: a marker of vascular dysfunction and progressive vascular disease. Br J Haematol 92: 747-750

55. Zumbach M, Hofmann M, Borcea V et al. (1997) Tissue Factor antigen is elevated in patients with microvascular complications of diabetes mellitus. Exp Clin Endocrinol Diabetes 105: 206-212

56. Bazzan M, Gruden G, Stella S et al. (1998) Microalbuminuria in IDDM is associated with increased expression of monocyte procoagulant activity. Diabetologia 41: 767-771

57. Utsunomiya $\mathrm{K}$, Ohta $\mathrm{H}$, Kurata $\mathrm{H}$, Tajima $\mathrm{N}$, Isogai $\mathrm{Y}$ (1995) The effect of macrophage colony-stimulating factor (M-CSF) on the progression of lipid-induced nephrotoxicity in diabetic nephropathy. J Diabetes Complications 9: 292-295

58. Beg AA, Sha WT, Bronson RT, Ghosh S, Baltimore D (1995) Embryonic lethality and liver degeneration in mice lacking the RelA component of NF-кB. Nature 376: $167-170$

59. Baichwal VR, Baeuerle PA (1997) Apoptosis: Activate NF- $\kappa \mathrm{B}$ or die? Current Biology 7: R94-R96 